\title{
Effects of different sizes silica nanoparticle on the liver, kidney and brain in rats: Biochemical and histopathological evaluation
}

\author{
Ülkü ÇÖMELEKOĞLU 1 * (D) , Ebru BALli ${ }^{2}$ (D) , Serap YALIN ${ }^{3}$ (D), Pelin EROĞLU 4 (D), \\ Gülsen BAYRAK ${ }^{2}$ iD , Selma YAMAN 5 (D) , Fatma SÖĞÜT 6 (D) \\ 1 Mersin University, Faculty of Medicine, Department of Biophysics, Mersin, Turkey. \\ 2 Mersin University, Faculty of Medicine, Department of Histology and Embryology, Mersin, Turkey. \\ 3 Mersin University, Faculty of Pharmacy, Department of Biochemistry, Mersin, Turkey. \\ 4 Mersin University, Faculty of Science and Literature, Department of Chemistry, Mersin, Turkey. \\ 5 Kahramanmaraş Sütçü İmam University, Faculty of Medicine, Department of Biophysics, Kahramanmaraş, Turkey. \\ 6 Mersin University, Vocational School of Medical Services, Department of Perfusion Technology, Mersin, Turkey. \\ * Corresponding author: E-mail: ulkucomelekoglu@mersin.edu.tr (Ü.Ç.); Tel: +90-324-361 0001.
}

Received: 04 September 2018 / Revised: 05 November 2018 / Accepted: 08 November 2018

\begin{abstract}
Silica is among the most popular nanoparticles. Large-scale production and use have increased the risk of human exposure to silica nanoparticles $\left(\mathrm{SiO}_{2} \mathrm{NPs}\right)$. This study aimed to investigate the toxic effects on the kidney, liver and brain of the $\mathrm{SiO}_{2} \mathrm{NPs}$. Twenty eight male Wistar albino rats were divided into four groups ( $\mathrm{n}=7$ rats) as control (1 $\mathrm{mL} /$ day physiological saline administration for 28 day $), 6 \mathrm{~nm} \mathrm{SiO}{ }_{2} \mathrm{NP}(6 \mathrm{~nm}, 150 \mu \mathrm{g} / \mathrm{mL} /$ day for 28 day $), 20 \mathrm{~nm} \mathrm{SiO}{ }_{2} \mathrm{NP}$ $\left(20 \mathrm{~nm}, 150 \mu \mathrm{g} / \mathrm{mL} /\right.$ day for 28 day) and $50 \mathrm{~nm} \mathrm{SiO}{ }_{2} \mathrm{NP}(50 \mathrm{~nm}, 150 \mu \mathrm{g} / \mathrm{mL} /$ day for 28 day) groups. After the last administration, rats were sacrificed and kidney, liver and brain samples were taken for biochemical and histological investigation. In all groups, malondialdehyde (MDA) levels, superoxide dismutase (SOD) and catalase (CAT) activities were measured using the spectrophotometric methods. Ultrastructural changes of tissues were evaluated using transmission electron microscopy. In the kidney tissue, the MDA level significantly increased in the 6 and $50 \mathrm{~nm}$ groups, while the similar increase was observed in the $6 \mathrm{~nm}$ group of the liver and 20 and $50 \mathrm{~nm}$ groups of the brain. SOD activity significantly increased in the 6,20 and $50 \mathrm{~nm}$ groups in brain and kidney tissues, but no significant change was observed in the liver tissue groups. Catalase activity decreased in the kidneys at 6 and $50 \mathrm{~nm}$ groups and increased in the 20 and $50 \mathrm{~nm}$ groups in liver and brain tissues. Ultrastructurally, kidney and liver tissues had normal morphological features in all groups. Degenerative changes were observed in the nerve fibers and axoplasm of myelinated and unmyelinated nerve fibers in $6 \mathrm{nM}, 20 \mathrm{nM}$ and $50 \mathrm{nM} \mathrm{SiO}_{2} \mathrm{NP}$ groups in the brain. These findings showed that exposure to 6, 20 and $50 \mathrm{~nm}$ sizes $\mathrm{SiO}_{2} \mathrm{NPs}$ may cause toxic effects in the liver, kidney and brain.
\end{abstract}

KEYWORDS: Silica nanoparticle; oxidative stress; kidney; liver; brain; histopathology.

\section{INTRODUCTION}

Nanoparticles have a size ranging from 1 to $100 \mathrm{~nm}$. Nanoparticles can be made of materials of diverse chemical nature, the most common being metals (gold, silver, nickel etc.), metal oxides (titanium dioxide, zinc oxide, silicon dioxide etc.), non-oxide ceramics, polymers, organics, carbon and biomolecules. These particles have numerous field including optics, electronics, and textiles, as well as applications in medicine [2] and pharmacy [3, 4]. Humans have been exposed to various nano-scale materials since birth, and the use of nanomaterials creates another threat to human life. Nanoparticles can enter into the body through inhalation, skin, and digestion. Because of their small size, nanoparticles may pass the barriers of biological systems [5] and may reach the most sensitive organs [6,7]. The toxic effects of nanoparticles on biological systems substantially depend on the physicochemical characteristics of the materials [8-10]. Reduction of the size of nanomaterials lead to an exponential increase in the surface area and the more reactive the nanomaterial surface [11]. Additionally, surface charge, surface area and shape plays an important role in toxicity of nanoparticles as it largely defines their interactions with the biological systems [12]. Recent studies suggested toxicities associated with the exposure of biological systems to different nanoparticles may be due to different causes, such as membrane damage [13, 14], oxidative stress [15, 16], cytotoxicity $[17,18]$ genotoxicity $[19,20]$.

How to cite this article: Çömelekoğlu Ü, Ballı E, Yalın S, Eroğlu P, Bayrak G, Yaman S, Söğüt F. Effects of different sizes silica nanoparticle on the liver, kidney and brain in rats: Biochemical and histopathological evaluation. J Res Pharm. 2019; 23(3): 344-353. 
Among the nanoparticles produced from different metals, silica nanoparticles $\left(\mathrm{SiO}_{2} \mathrm{NPs}\right)$, because of the favourable properties such as smaller size increased surface-to-volume ratio, a higher surface reactivity, high drug loading efficiency, ease of large-scale synthesis and low cost of NP production have been used in many different area such as mechanical polishing, additives to food, optical imaging, cancer therapy, targeted drug delivery, controlled drug release for genes and proteins [21-23]. This widespread use of $\mathrm{SiO}_{2}$ nanoparticles in many areas has also led to the search for toxic effects on human and environmental health. Recently, a number of researchers have found $\mathrm{SiO}_{2} \mathrm{NPs}$ responsible for toxicity in different organs [24-32].

Toxicology studies have suggested that $\mathrm{SiO}_{2} \mathrm{NPs}$ can induce adverse effects in the liver, kidney and brain $[27,33,34]$. Since the information about the effects on oxidative stress and ultrastructure of tissues are limited, the present study aimed to evaluate the ability of different sizes $\mathrm{SiO}_{2} \mathrm{NPs}$ to induce oxidative stress and ultrastructural changes in the liver, kidney and brain of male albino rats as mammalian model, during subacute treatment.

\section{RESULTS}

\subsection{Nanoparticle characterization}

XRD results demonstrated a broad peak at about $2 \theta=22^{\circ}$, which reveals the amorphous nature of the $\mathrm{SiO}_{2} \mathrm{NPs}$. The shape and size of particles were verified by FE-SEM images. FE-SEM imaging of the nanoparticles showed uniform spherical structures with size of about 6, 20 and $50 \mathrm{~nm}$. This result is also confirmed by DLS measurement

\subsection{Biochemical findings}

Among control tissues, MDA level was highest in kidney, whereas liver and brain showed lower amounts (Table 1). Organ-specific responses were seen when tissues were exposed to $\mathrm{SiO}_{2} \mathrm{NPs}_{\mathrm{N}}$ for 28 day. Exposure to $6 \mathrm{~nm}$ sized $\mathrm{SiO}_{2} \mathrm{NPs}$ had no effect on MDA levels in brain tissue, whereas kidney and liver showed a significant increase of by $126 \%$ and $65.7 \%$, respectively when compared to control group $(p<0.05)$. At the $20 \mathrm{~nm}$ sized $\mathrm{SiO}_{2} \mathrm{NPs}$ exposure was not changed MDA level in kidney and liver $(\mathrm{p}>0.05)$ but it was significantly increased in brain by $346.6 \%$ as compared with the control value $(\mathrm{p}<0.05)$. A similar upward trend was seen at the $50 \mathrm{~nm}$ sized exposure. $50 \mathrm{~nm}$ sized $\mathrm{SiO}_{2} \mathrm{NPs}$ exposure was increased MDA level in kidney, liver and brain by $88.38 \%, 31.14 \%$ and $533.3 \%$, respectively, but the value in liver was not significantly different from the control.

Table 1. Means of MDA level (nmol/mg protein) in liver, kidney and brain. All data were presented as mean \pm SD.

\begin{tabular}{cccc}
\hline Groups & Kidney & Liver & Brain \\
\hline Control & $15.5 \pm 7.8$ & $6.1 \pm 1.2$ & $1.5 \pm 0.9$ \\
$6 \mathrm{~nm} \mathrm{SiO}_{2}$ & $35.1 \pm 14.7 \mathrm{a}, \mathrm{c}$ & $10.1 \pm 3.7 \mathrm{a}$ & $3.7 \pm 1.3$ \\
$20 \mathrm{~nm} \mathrm{SiO} 2$ & $17.6 \pm 2.5$ & $8.6 \pm 3.7$ & $6.7 \pm 2.8 \mathrm{a}, \mathrm{b}, \mathrm{c}$ \\
$50 \mathrm{~nm} \mathrm{SiO} 2$ & $29.2 \pm 10.6^{\mathrm{a}, \mathrm{b}}$ & $8.0 \pm 4.2$ & $9.5 \pm 1.3 \mathrm{a}, \mathrm{b}$ \\
\hline a Difference is statistically significant from control group; & & \\
b Difference is statistically significant from 6 nm group; & \\
c Difference is statistically significant from 50 nm group; Post-hoc: Tukey test; a:0,05; Anova
\end{tabular}

In control tissues, the activity of SOD was highest in liver, intermediate in kidney and lowest in brain (table 2). In the kidney tissue, SOD activity increased significantly in 6, 20 and $50 \mathrm{~nm}$ groups by $67.58 \%, 120 \%$ and $111.26 \%$, respectively as compared with control value $(\mathrm{p}<0.05)$. In the liver, SOD activity did not change at all three groups $(\mathrm{p}>0.05)$. In the brain, SOD activity significantly increased in 6,20 and $50 \mathrm{~nm}$ groups $(\mathrm{p}<0.05)$ by $48 \%, 118 \%$ and $251 \%$, respectively as compared to control value $(\mathrm{p}<0.05)$.

CAT activity showed remarkable differences between the three tissues studied. In control tissues, catalase activity was extremely high in kidney and very low liver and brain (table 3). In kidney CAT activity significantly decreased in 6 and $50 \mathrm{~nm}$ groups as compared with control group $(p<0.05)$. There was no significant differences between $20 \mathrm{~nm}$ group and other groups $(\mathrm{p}>0.05)$. CAT activity decreased in 6,20 and $50 \mathrm{~nm}$ groups by $37 \%, 8 \%$ and $35 \%$ respectively. In liver tissue, CAT activity increased in 6,20 and $50 \mathrm{~nm}$ groups by $11.7 \%, 123.1 \%$ and $170 \%$, respectively as compared with control value. These increasing was significant in 20 and $50 \mathrm{~nm}$ groups ( $\mathrm{p}<0.05)$. There was no significant change in $6 \mathrm{~nm}$ group $(\mathrm{p}>0.05)$. Similarly, 
in the brain, CAT activity increased by $1.53 \%, 66,7 \%$ and $105.9 \%$ in 6,20 and $50 \mathrm{~nm}$, respectively as compared with control group $(\mathrm{p}<0.05)$. There was no significant change in $6 \mathrm{~nm}$ group $(\mathrm{p}>0.05)$.

Table 2. Means of SOD activity (IU/mg protein) in liver, kidney and brain. All data were presented as mean \pm SD.

\begin{tabular}{cccc}
\hline Groups & Kidney & Liver & Brain \\
\hline Control & $3.64 \pm 1.30$ & $5.83 \pm 2.97$ & $3.00 \pm 1.90$ \\
$6 \mathrm{~nm} \mathrm{SiO}_{2}$ & $6.10 \pm 1.75^{\mathrm{a}}$ & $5.79 \pm 2.34$ & $5.35 \pm 1.34^{\mathrm{a}}$ \\
$20 \mathrm{~nm} \mathrm{SiO}_{2}$ & $8.03 \pm 1.88^{\mathrm{a}}$ & $5.36 \pm 2.04$ & $6.54 \pm 2.66^{\mathrm{a}}$ \\
$50 \mathrm{~nm} \mathrm{SiO}_{2}$ & $7.69 \pm 1.08^{\mathrm{a}}$ & $7.11 \pm 3.31$ & $10.54 \pm 1.34^{\mathrm{a}, \mathrm{b}, \mathrm{c}}$ \\
\hline
\end{tabular}

a Difference is statistically significant from control group;

${ }^{\mathrm{b}}$ Difference is statistically significant from $6 \mathrm{~nm}$ group;

c Difference is statistically significant from 20 nm group; Post-hoc: Tukey test; $a: 0,05$; Anova

Table 3. Means of CAT activity (IU/mg protein) in liver, kidney and brain. All data were presented as mean \pm SD.

\begin{tabular}{cccc}
\hline Groups & Kidney & Liver & Brain \\
\hline Control & $703.4 \pm 74.9$ & $14.76 \pm 7.76$ & $18.30 \pm 5.47$ \\
$6 \mathrm{~nm} \mathrm{SiO}_{2}$ & $443.1 \pm 118.9^{\mathrm{a}}$ & $16.49 \pm 6.71$ & $18.58 \pm 4.08$ \\
$20 \mathrm{~nm} \mathrm{SiO}_{2}$ & $653.7 \pm 189.1$ & $32.94 \pm 17.27 \mathrm{a}$ & $30.51 \pm 7.82^{\mathrm{a}}$ \\
$50 \mathrm{~nm} \mathrm{SiO}_{2}$ & $459.4 \pm 237.3^{\mathrm{a}}$ & $39.94 \pm 16.5^{\mathrm{a}, \mathrm{b}}$ & $37.69 \pm 14.06^{\mathrm{a}}$ \\
\hline
\end{tabular}

a Difference is statistically significant from control group;

${ }^{\mathrm{b}}$ Difference is statistically significant from $6 \mathrm{~nm}$ group: Post-hoc: Tukey test; a:0,05; Anova

\subsection{Histological findings}

Kidney, liver and brain tissue sections of all groups were examined ultrastructurally. In the kidney, the glomerules have normal ultrastructural features in all groups (Figure 1A, 1B, 1C and 1D). The visceral epithelial cells and foot processes of these cells have normal morphological features. In addition endothelium of the glomerular capillaries and glomerular basement membranes were detected as normal (Figure 1A, 1B, 1C and 1D).

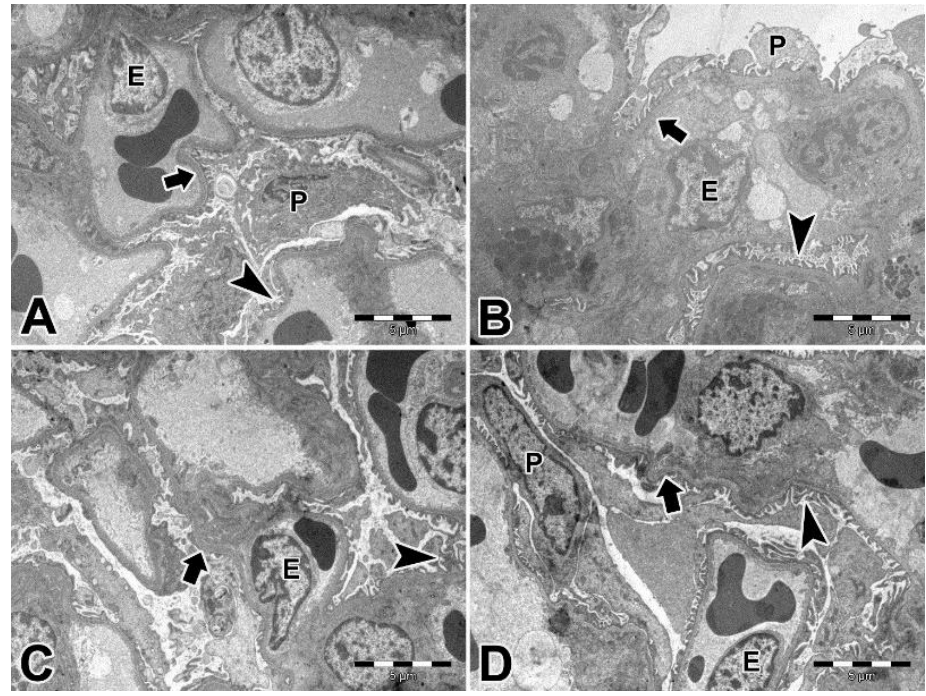

Figure 1. Kidney. A: Control group, B: $6 \mathrm{~nm}$ group, C: $20 \mathrm{~nm}$ group, D; $50 \mathrm{~nm}$ group. Podocyte (P), endothelial cell (E), glomerular basement membrane (arrow), foot processes of podocyte (arrow head), x5000.

The hepatocytes and bile canaliculi in liver tissues have normal morphological features in all groups (Figure 2A, 2B, 2C and 2D). 


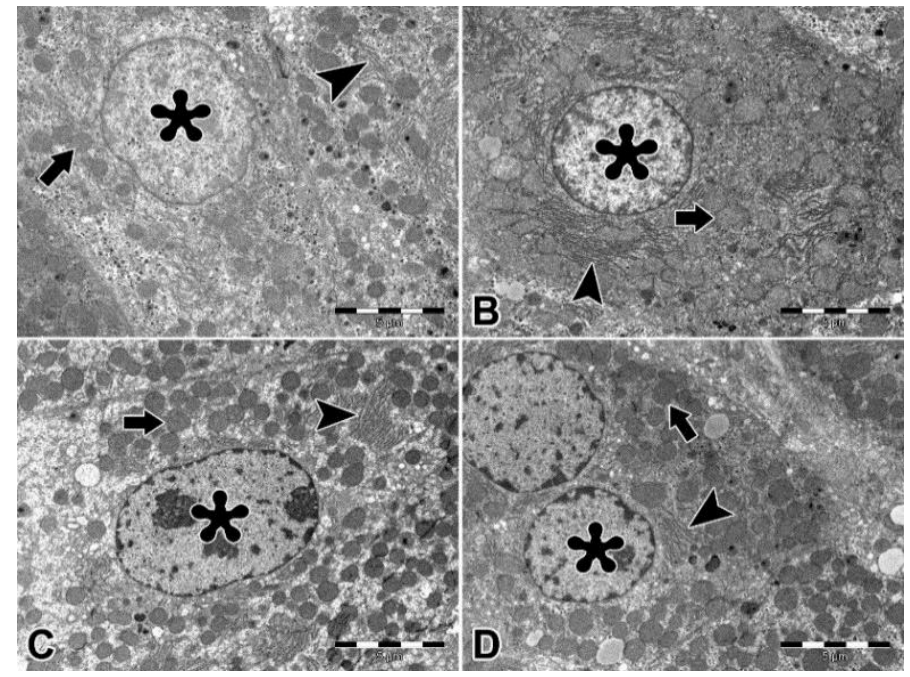

Figure 2. Liver. A: Control group, B: $6 \mathrm{~nm}$ group, C: $20 \mathrm{~nm}$ group, D; $50 \mathrm{~nm}$ group. The hepatocytes have normal morphologic characteristics. Nucleus (asterisk), mitochondrion (arrow), rough endoplasmic reticulum (arrow head), x6000.

In the brain tissue of control group, neurons, myelinated and unmyelinated nerve fibers, glial cells and perivascular area were found to be normal in structure (Figure 3A, 3B, 3C and 3D).

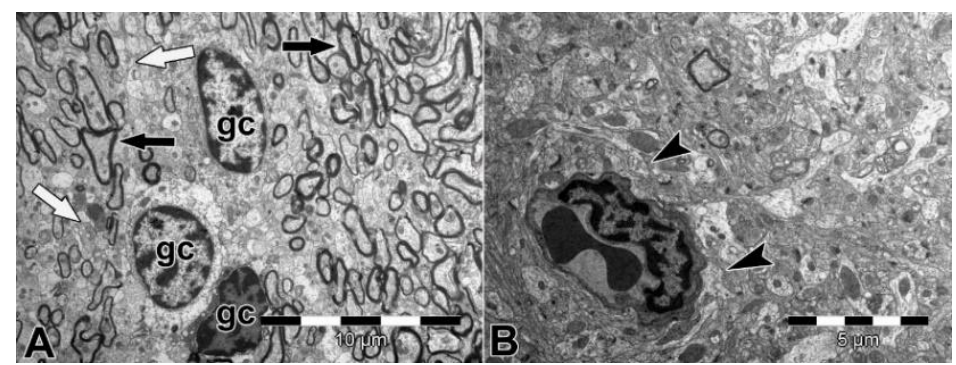

Figure 3. Brain. Control group. A: Myelinated (black arrows) and unmyelinated (white arrows) nerve fibers, glial cells (gc), x5000. B: Perivascular area (black arrowhead), x7500.

In the myelin sheath of nerve fibers and axoplasms of myelinated and unmyelinated nerve fibers that have degenerative changes were observed in $6 \mathrm{~nm}$ (Figure 4A, 4B), $20 \mathrm{~nm}$ (Figure 4C, 4D) and $50 \mathrm{~nm}$ groups (Figure 5A, 5B, 5C and 5D). In addition, axonal vacuols of unmyelinated nerve fibers were found in $6 \mathrm{~nm}, 20$ $\mathrm{nm}$ and $50 \mathrm{~nm}$ groups. The perivascular area was detected as normal in $6 \mathrm{~nm}$ and $20 \mathrm{~nm}$ groups (Figure 4A, $4 \mathrm{~B}, 4 \mathrm{C}$ and $4 \mathrm{D}$ ). However, perivascular edema was observed in the $50 \mathrm{~nm}$ group (Figure 5D). In addition, nuclear and intracytoplasmic vacuols in some neurons were observed in the $50 \mathrm{~nm}$ group (Figure 5C).

\section{DISCUSSION}

In the current study, the effects of 6,20 and $50 \mathrm{~nm}$ sized $\mathrm{SiO}_{2} \mathrm{NPs}$ on kidney, liver and brain were investigated by using biochemical and histopathological methods. Our findings indicated that different sizes $\mathrm{SiO}_{2} \mathrm{NPs}$ cause oxidative stress in the liver, kidney and brain, and additionally, lead to structural damage in the brain tissue.

Oxidative stress is the result of an imbalance between intracellular production of free radicals and cellular defense mechanisms. The balance between oxidant and antioxidant agents may be impaired by an increase in free radicals or by reducing anti-oxidative substances. Oxidative stress can trigger a number of potentially harmful biochemical reactions [35]. Nanoparticles have been shown to produce reactive oxygen species (ROS) via prooxidant functional groups, active redox cycling and particle-cell interactions [36]. ROS constitute a pool of oxidative species including superoxide anion, hydroxyl radical, hydrogen peroxide, singlet oxygen. The antioxidant defense mechanism is very important in response to ROS toxicity. SOD is the first line of the defense mechanism and scavenges superoxide radicals. CAT are other key enzymes in the antioxidant mechanism. They are responsible in the conversion of $\mathrm{H}_{2} \mathrm{O}_{2}$ into $\mathrm{H}_{2} \mathrm{O}$ and molecular $\mathrm{O}_{2}$. The decomposition product of the polyunsatured fatty acids, MDA, is produced naturally as a result of lipid peroxidation and is often used as an indicator of oxidative damage at the cellular level [37]. 


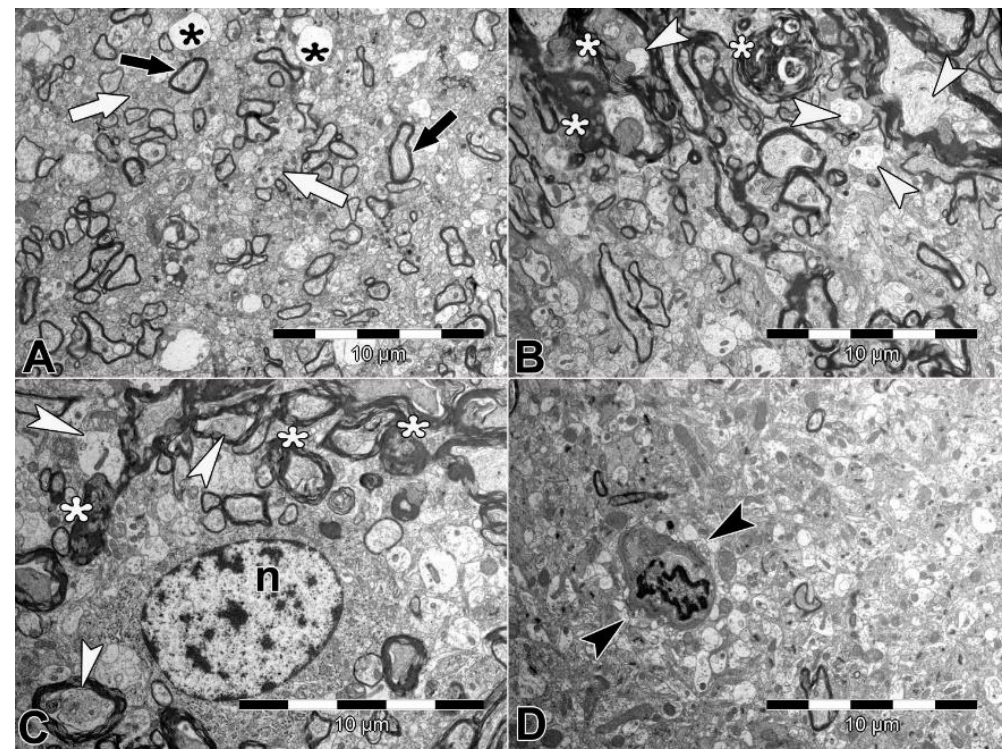

Figure 4. Brain. A: $6 \mathrm{~nm}$ group. Myelinated (black arrows) and unmyelinated (white arrows) nerve fibers, axonal vacuols in unmyelinated nerve fibers (black asterisks), x5000. B: $6 \mathrm{~nm}$ group. Degeneration of myelin sheath (white asterisks), degeneration of myelinated and unmyelinated nerve fibers (white arrowhead), x5000. C: $20 \mathrm{~nm}$ group. Neuron (n), degeneration of myelin sheath (white asterisks), degeneration of myelinated and unmyelinated nerve fibers (white arrowhead), x6000. D:20 nm group. Perivascular area (black arrowhead), x5000.

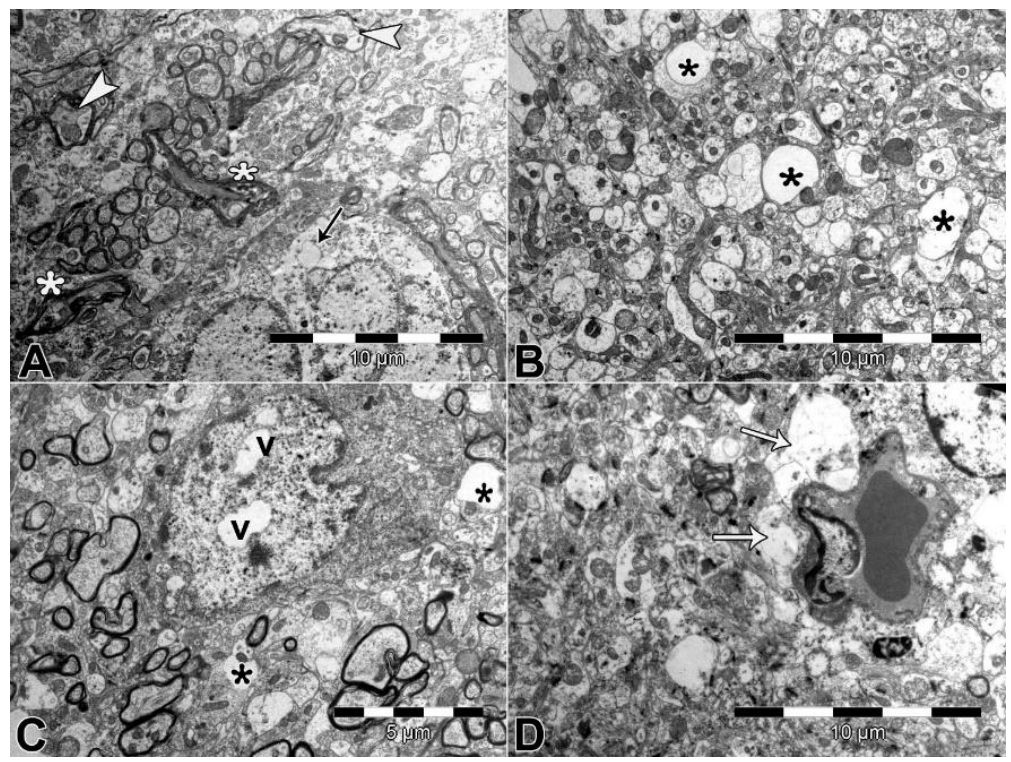

Figure 5. Brain. $50 \mathrm{~nm}$ group. A: Degeneration of myelin sheath (white asterisks) and myelinated nerve fibers (white arrowhead), intracytoplasmic vacuols in neuron (thin black arrows), x5000. B: Axonal vacuols of unmyelinated nerve fibers (black asterisks), x6000. C: Axonal vacuols of unmyelinated nerve fibers (black asterisks), nuclear vacuols in neuron (v), x7500. D: Perivascular edema (thin white arrows), x6000.

In this study, to evaluate oxidative stress MDA level, SOD and CAT activities were measured in samples of tissue. Kidney, liver and brain tissues had different characteristics in response to the different sizes of $\mathrm{SiO}_{2}$ NPs. In the kidney tissue, the MDA level significantly increased in the 6 and $50 \mathrm{~nm}$ groups, while the similar increase was observed in the $6 \mathrm{~nm}$ group of the liver and 20 and $50 \mathrm{~nm}$ groups of the brain. SOD activity significantly increased in the 6,20 and $50 \mathrm{~nm}$ groups in brain and kidney tissues, but no significant change was observed in the liver tissue groups. CAT activity decreased in the kidneys at 6 and $50 \mathrm{~nm}$ groups and increased in the 20 and $50 \mathrm{~nm}$ groups in liver and brain tissues. In recent years, in vivo and in vitro studies have shown that free oxygen radicals develop in response to $\mathrm{SiO}_{2} \mathrm{NPs}$. Chatteria et al. investigated the mechanisms involved in amorphous silica nanoparticles mediated hepatotoxicity and suggested that the 
depletion of glutathione metabolism and increase of oxidative stress are among the principal causes of a silicamediated hepatotoxicity [38]. Yu et al. [39] reported that intravenous injection of $\mathrm{SiO}_{2} \mathrm{NPs}_{\text {induced hepatic }}$ granuloma formation, oxidative damage, and apoptosis. Sadek et al. [40] found that administration of SiNPs, for 15 consecutive days, caused changes in oxidative stress parameters such as malondialdehyde, glutathione reduced, catalase, superoxide dismutase, glutathione reductase, and glutathione peroxidase. In addition, they reported that administration of silica nanoparticles induced changes in liver tissue architecture [40]. Nemmar et al. [27] investigated the acute (24 hours) effects of intraperitoneally administered $50 \mathrm{~nm}$ silica nanoparticles $(0.25 \mathrm{mg} / \mathrm{kg})$ on systemic toxicity, oxidative stress, inflammation, and DNA damage in the lung, heart, liver, kidney, and brain of mice. They found that lipid peroxidation was significantly increased by silica nanoparticles in the lung, liver, kidney, and brain, but was not changed in the heart [27]. Passagne et al. [41] investigated that the cytotoxicity of nano- $\mathrm{SiO}_{2}$ of different sizes $(20$ and $100 \mathrm{~nm})$ on two renal proximal tubular cell lines (human HK-2 and porcine LLC-PK(1)) and they found that the 20 and $100 \mathrm{~nm}$ nano-SiO${ }_{2}$ caused oxidative stress. However, they observed that the toxic effect of $20 \mathrm{~nm} \mathrm{SiO}{ }_{2}$ was more powerful. Although many studies have reported that oxidative stress induced by nanoparticles is dependent on the nanoparticle size but no relationship has been observed in this study. Although many studies have reported that oxidative stress induced by nanoparticles was size dependent, in our study it was independent of $\mathrm{SiO}_{2} \mathrm{NP}$ size. While $\mathrm{SiO}_{2}$ nanoparticles of 6 and $50 \mathrm{~nm}$ size in the kidney produced more oxidative stress, nanoparticles of 20 and $50 \mathrm{~nm}$ size were more effective in the brain. It was not possible to mention a more toxic nanoparticle size for the liver. The brain tissue produced more oxidative stress to $\mathrm{SiO}_{2}$ nanoparticles than to kidney and liver tissues. This difference between liver, kidney and brain tissues may be related to the fact that brain tissue is more sensitive to oxidative stress because of its high oxygen consumption, its weak antioxidative ability, and the terminal-differentiation feature of neurons [42].

In the present study, in addition to oxidative stress, ultrastructural evaluation of liver, kidney and brain tissue was performed. According to our histopathological findings, 6, 20 and $50 \mathrm{~nm}$ sized $\mathrm{SiO}_{2}$ nanoparticles did not cause any ultrastructural changes in the kidney and liver but they led to significant structural changes in the brain tissue. The most striking findings the brain tissue was degenerative changes in myelinated and unmyelinated nerve fibers. Some of the studies that report on toxicity of $\mathrm{SiO}_{2}$ nanoparticles in rats or mice show that toxicity in the liver, kidney and brain, while some other studies report that silica NPs have no adverse effect and can be used safely. Shaimaa et al. [43] assessed the effect of different doses and durations of intravenous injections of $\mathrm{SiO}_{2} \mathrm{NPs}$ on the hepatic tissue structure of adult male albino rats. They injected with $10 \mathrm{mg} / \mathrm{kg}$ and $30 \mathrm{mg} / \mathrm{kg} \mathrm{SiO} \mathrm{SPs}_{2}$ for two and four weeks and evaluated histological, immunohistochemical and ultrastructure changes. They reported that $\mathrm{SiO}_{2} \mathrm{NPs}$ injections didn't affect the hepatic lobular organization in any dose or duration but they caused hepatocytes structural changes, hepatic granulomatous inflammatory reaction accompanied by localized fibrosis, being prominent with increasing $\mathrm{SiO}_{2} \mathrm{NPs}^{\prime}$ dose and duration of administration. Vidya and Chitra [44] investigated the effects of $1 \mathrm{~nm} \mathrm{SiO} \mathrm{NPs}_{2}$ at sublethal concentration, $12 \mathrm{mg} / \mathrm{L}$ were exposed to the freshwater fish, for $96 \mathrm{~h}$ and 60 days. They observed that major hepatic lesions includes loss of normal tissue architecture, segmentation of hepatocytes, vacuolization, spindle shaped nucleus and necrosis. Brain tissue of the treated fish showed degeneration of nerve cells, formation of vacuolization, cerebral edema, necrosis of neurofibrillar region and lesion in choroid plexus. Yu et al. [45] evaluated the acute toxicity at $14 \mathrm{~d}$ after intravenous injection of SNPs at 29.5, 103.5 and $177.5 \mathrm{mg} / \mathrm{kg}$ in mice. They showed that lymphocytic infiltration, granuloma formation, and hydropic degeneration in liver hepatocytes and macrophage proliferation in the liver by A CD68 immunohistochemistry stain. They didn't observed significant changes in morphology of kidney and brain in the SiNP treated mice. Chan et al. [34] investigated the in vivo toxicity of SiNPs of $150 \mathrm{~nm}$ in various dosages via intravenous administration in mice. Blood examinations showed no definite systemic dysfunction of organ systems. Histopathological studies of vital organs confirmed no SiNP-related adverse effects. They concluded that 150 $\mathrm{nm}$ SiNPs were biocompatible and safe for in vivo use in mice. Lai et al. [46] investigated the subchronic oral toxicity of silica nanoparticles (NPs) and silica microparticles (MPs) in rats. Their study demonstrated that neither silica NPs nor silica MPs induced toxicological effects after subchronic oral exposure in rats. The sizes, dosage, physiochemical properties and route of entry of the $\mathrm{SiO}_{2}$ nanoparticles used in these studies are different. The controversial results in toxic effects may be related to these differences.

There are some limitations in this study. Firstly, we tested single concentration $(150 \mu \mathrm{g} / \mathrm{mL})$ for the $\mathrm{SiO}_{2} \mathrm{NPs}$. It is possible that higher concentration of $\mathrm{SiO}_{2} \mathrm{NPs}$ may induce oxidative damage that was not detectable in this concentration. The toxic effect of $\mathrm{SiO}_{2} \mathrm{NPs}$ could be investigated in a dose-dependent manner. Secondly, it was used only the ultrastructural technique to investigare tissue damage. Different techniques such as immunohistochemistry could be used for this. 


\section{CONCLUSION}

We conclude that subchronic systemic exposure to 6, 20 and $50 \mathrm{~nm}$ size and $150 \mathrm{mg} / \mathrm{mL} \mathrm{SiO}{ }_{2} \mathrm{NPs}_{\text {causes }}$ oxidative stress in the liver, kidney and brain. In addition, it causes structural changes in the brain that are compatible with neurotoxicity. The effects of $\mathrm{SiO}_{2} \mathrm{NPs}$ must be thoroughly investigated before they can be used in humans.

\section{MATERIALS AND METHODS}

\subsection{Nanoparticle preparation and characterization}

In this study, 6, 20 and $50 \mathrm{~nm}$ diameter $\mathrm{SiO}_{2} \mathrm{NPs}$ were used. The $\mathrm{SiO}_{2} \mathrm{NPs}$ were prepared according to Stober method (Costa et al.) and characterized according to the procedures reported in the our previous studies [24, 25]. For synthesis, $0.1 \mathrm{~mL}$ APTES, $1.2 \mathrm{~mL}$ TEOS, $1.2 \mathrm{~mL} \mathrm{NH} \mathrm{H}_{4} \mathrm{OH}$ and $5 \mathrm{~mL}$ ethanol were mixed homogeneously under an inert atmosphere overnight. thereafter, the nanoparticles were washed with absolute ethanol for five times to remove unreacted chemicals. The sizes of nanoparticles were adjusted by changing the precursor concentrations. Advanced X-ray diffractometer (XRD) (Bruker D8), field emissionscanning electron microscopy (FE-SEM) (Zeiss/Supra 55 FE-SEM) and dynamic light scattering (DLS) (Zetasizer Nano ZS) were used for the characterization of $\mathrm{SiO}_{2} \mathrm{NPs}$.

\subsection{Animals}

In the present study, twenty eight healthy adult male Wistar albino rats weighing 180-250 g were used and the rats were housed in stainless steel cages ( 7 rats per cage) at $24 \pm 1.5^{\circ} \mathrm{C}$ and $55 \%$ humidity level under the 12:12 $\mathrm{h}$ day-night cycle. Rats were fed with standard laboratory rat diet and fresh drinking water were provided ad libitum. Experimental protocol was approved by Mersin University Experimental Animals Local Ethics Committee (approval number: 12.04.2016/5260294-050/85248). All experiments were carried out in accordance with the National Institutes of Health's Guide for the Care and Use of Laboratory Animals.

\subsection{Experimental Design}

Twenty eight male Wistar albino rats were equally divided into four groups ( $\mathrm{n}=7$ rats) as control $(1 \mathrm{~mL}$ $0.9 \%$ saline per day, intraperitoneally for 28 day $), 6 \mathrm{~nm} \mathrm{SiO}{ }_{2} \mathrm{NP}(6 \mathrm{~nm}, 150 \mu \mathrm{g} / \mathrm{mL} /$ day, intraperitoneally for 28 day), $20 \mathrm{~nm} \mathrm{SiO} 2 \mathrm{NP}\left(20 \mathrm{~nm}, 150 \mu \mathrm{g} / \mathrm{mL} /\right.$ day, intraperitoneally for 28 day) and $50 \mathrm{~nm} \mathrm{SiO}{ }_{2} \mathrm{NP}$ (50 nm, 150 $\mu \mathrm{g} / \mathrm{mL} /$ day, intraperitoneally for 28 day) groups.

The animals were sacrificed at one day after end administration by cervical dislocation. The liver, kidney and brain samples were excised. These samples were used for biochemical and histological analyses.

\subsection{Biochemical evaluation}

The MDA level was measured in homogenized kidney, liver and brain tissues by the following procedure according to Yagi [47]. Briefly, $50 \mu \mathrm{L}$ of homogenate were mixed with $100 \mu \mathrm{L}$ of $8.1 \%$ sodium dodecyl sulfate (SDS), $750 \mu \mathrm{L}$ of $20 \%$ TCA (pH:3.5) $750 \mu \mathrm{L}$ of $0.8 \%$ TBA and $350 \mu \mathrm{L}$ distilled water. The mixtures were incubated in a boling water bath for $30 \mathrm{~min}$. After cooling, $2.5 \mathrm{~mL}$ of n-butanol pyridine and $500 \mu \mathrm{L}$ distilled water were added and mixed. The reaction mixture was centrifuged at 3,500 rpm for $15 \mathrm{~min}$. The absorbance of the supernatant was measured at $532 \mathrm{~nm}$. The MDA levels were expressed as $\mathrm{nmol} / \mathrm{mg}$ protein. SOD activity was assayed spectrophotometrically in tissue samples according to the method of the Sun et al. [48]. Briefly, supernatant was incubated with xanthine and xanthine oxidase and then nitroblue tetrazolium (NBT) was added. Thereafter, blue formazan was monitored at $560 \mathrm{~nm}$. The activity of SOD was expressed as IU mg-1 protein. Activity of catalase was evaluated based on a previously described method [49]. The decomposition of $\mathrm{H}_{2} \mathrm{O}_{2}$ was monitored spectrophotometrically at $240 \mathrm{~nm}$. Specific activity was defined as micromole substrate decomposed per minute per milligram of protein ( $\mathrm{U} / \mathrm{mg}$ protein). Protein concentration in homogenates was determined based on the procedure described by Lowry et al. [51] using bovine serum albumin as standard. Absorbance of samples was measured by spectrophotometer at $750 \mathrm{~nm}$.

Author contributions: Concept- Ü.Ç., S.Y., E.B.; Design- Ü.Ç., S.Y., E.B.; Supervision-Ü.Ç.; Resource-Ü.Ç.; MaterialsÜ.Ç., S.Y,. E.B.; Data Collecting and/or processing-Ü.Ç., E.B., S.Y., P.E., G.B., S.Y., F.S.; Analysis and/or interpretationÜ.Ç., E.B., S.Y.; Literature search- Ü.Ç., S.Y., E.B., P.E., G.B., S.Y., F.S.; Writing- Ü.Ç., E.B., S.Y.; Critical Reviews- Ü.Ç., E.B., S.Y., P.E., G.B., S.Y., F.S.

Conflict of interest statement: "The authors declared no conflict of interest" in the manuscript. 


\section{REFERENCES}

[1] Alkilany AM, Murphy CJ. Toxicity and cellular uptake of gold nanoparticles: what we have learned so far? J Nanopart Res. 2010;12(7):2313-2333. [CrossRef]

[2] Salata O. Applications of nanoparticles in biology and medicine. J Nanobiotechnology. 2004; 2(1):1-6. [CrossRef]

[3] Jin S, Ye K. Nanoparticle-mediated drug delivery and gene therapy. Biotechnol Prog. 2007;23(1):32-41. [CrossRef]

[4] Singh R, Lillard JW Jr. Nanoparticle-based targeted drug delivery. Exp Mol Pathol. 2009;86(3):215-223. [CrossRef]

[5] Sarin H, Kanevsky AS, Wu H, Brimacombe KR, Fung SH, Sousa AA, Auh S, Wilson CM, Sharma K, Aronova MA, Leapman RD, Griffiths GL, Hall MD. Effective transvascular delivery of nanoparticles across the blood-brain tumor barrier into malignant glioma cells. J Transl Med. 2008; 6:80. [CrossRef]

[6] Lockman PR, Koziara JM, Mumper RJ, Allen DD Nanoparticle surface charges alter blood-brain barrier integrity and permeability. J Drug Target. 2004;12(9-10):635-641. [CrossRef]

[7] Bahadar H, Maqbool F, Niaz K, Abdollahi M. Toxicity of nanoparticles and an overview of current experimental models. Iran Biomed J. 2016;20(1):1-11. [CrossRef]

[8] Yang H, Liu C, Yang D, Zhang H, Xi Z. Comparative study of cytotoxicity, oxidative stress and genotoxicity induced by four typical nanomaterials: the role of particle size, shape and composition. J Appl Toxicol. 2009;29(1):69-78. [CrossRef]

[9] Rivera Gil P, Oberdörster G, Elder A, Puntes V, Parak WJ. Correlating physico-chemical with toxicological properties of nanoparticles: the present and the future. ACS Nano. 2010; 4(10): 5527-5531. [CrossRef]

[10] Soenen SJ, Rivera-Gil P, Montenegro JM, Parak WJ, De Smedt SC, Braeckmans K. Cellular toxicity of inorganic nanoparticles: Common aspects and guidelines for improved nanotoxicity evaluation. Nanotoday. 2011; 6(5):446465. [CrossRef]

[11] Powers KW, Palazuelos M, Moudgil BM, Roberts SM. Characterization of the size, shape, and state of dispersion of nanoparticles for toxicological studies. Nanotoxicology. 2007;1(1):42-51. [CrossRef]

[12] Hoshino A, Fujioka K, Oku, T, Suga, M, Sasaki, YF, Ohta T, Yasuhara M, Suzuki K, Yamamoto K. Physicochemical properties and cellular toxicity of nanocrystal quantum dots depend on their surface modification. Nano Lett. 2004; 4(11): 2163-2169. [CrossRef]

[13] Karlsson HL, Cronholm P, Hedberg Y, Tornberg M, De Battice L, Svedhem S, Wallinder IO. Cell membrane damage and protein interaction induced by copper containing nanoparticles--importance of the metal release process. Toxicology. 2013;313(1):59-69. [CrossRef]

[14] Zhao J, Wang Z, Dai Y, Xing B. Mitigation of CuO nanoparticle-induced bacterial membrane damage by dissolved organic matter. Water Res. 2013;47(12):4169-4178. [CrossRef]

[15] Sarkar A, Ghosh M, Sil PC. Nanotoxicity: oxidative stress mediated toxicity of metal and metal oxide nanoparticles. J Nanosci Nanotechnol. 2014;14(1):730-743.

[16] Flores-López LZ, Espinoza-Gómez H, Somanathan RJ. Silver nanoparticles: Electron transfer, reactive oxygen species, oxidative stress, beneficial and toxicological effects. Appl Toxicol. 2019;39(1):16-26. [CrossRef]

[17] Adjei IM, Sharma B, Labhasetwar V. Nanoparticles: cellular uptake and cytotoxicity. Adv Exp Med Biol. 2014; 811:7391. [CrossRef]

[18] Braun K, Stürzel CM, Biskupek J, Kaiser U, Kirchhoff F, Lindén M. Comparison of different cytotoxicity assays for in vitro evaluation of mesoporous silica nanoparticles. Toxicol In Vitro. 2018;52:214-221. [CrossRef]

[19] Golbamaki A, Golbamaki N, Sizochenko N, Rasulev B, Leszczynski J, Benfenati E. Genotoxicity induced by metal oxide nanoparticles: a weight of evidence study and effect of particle surface and electronic properties. Nanotoxicology. 2018;9:1-17. [CrossRef]

[20] Ciğerci İH, Ali MM, Kaygısız ŞY, Kaya B, Liman R. Genotoxic assessment of different sizes of iron oxide nanoparticles and ionic iron in earthworm (Eisenia hortensis) coelomocytes by Comet assay and micronucleus test. Bull Environ Contam Toxicol. 2018; 101(1): 105-109. [CrossRef]

[21] Rahman IA, Padavettan V. Synthesis of silica nanoparticles by sol-gel: size-dependent properties, surface modification, and applications in silica-polymer nanocomposites - a review. J Nanomater. 2012; Article ID 132424 [CrossRef]

[22] Li Z, Barnes JC, Bosoy A, Stoddart JF, Zink JI. Mesoporous silica nanoparticles in biomedical applications. Chem Soc Rev. 2012; 41(7):2590-2605. [CrossRef] 
[23] Tang L, Cheng J. Nonporous silica nanoparticles for nanomedicine application. Nano Today. 2013;8(3): 290-312. [CrossRef]

[24] Wang F, Gao F, Lan M Yuan H, Huang Y, Liu J. Oxidative stress contributes to silica nanoparticle-induced cytotoxicity in human embryonic kidney cells. Toxicol In Vitro. 2009; 23:808-815. [CrossRef]

[25] Athinarayanan J, Periasamy VS, Alsaif MA Al-Warthan AA, Alshatwi AA. Presence of nanosilica (E551) in commercial food products: TNF-mediated oxidative stress and altered cell cycle progression in human lung fbroblast cells. Cell Biol Toxicol. 2014; 30:89-100. [CrossRef]

[26] Zhang XQ, Yin LH, Tang M, Pu YP. ZnO, $\mathrm{TiO}(2), \mathrm{SiO}(2)$ and $\mathrm{Al}(2) \mathrm{O}(3)$ nanoparticles-induced toxic effects on human fetal lung fbroblasts. Biomed Env Sci. 2011; 24:661-669. [CrossRef]

[27] Nemmar A, Yuvaraju P, Beegam S, Yasin J, Kazzam EE, Ali BH. Oxidative stress, inflammation, and DNA damage in multiple organs of mice acutely exposed to amorphous silica nanoparticles. Int J Nanomed 2016;11:919-928. [CrossRef].

[28] Balli E, Comelekoglu U, Yalin S, Battal D, Ocakoglu K, Sogut F, Yaman S, Turkseven CH, Eroglu P, Karagul I, Goney G, Yıldırımcan S, Aktas A. Toxic effects of silica nanoparticles on heart: electrophysiological, biochemical, histological and genotoxic study. Fres Environ Bull. 2016: 25(2): 612-622.

[29] Battal D, Çelik A, Güler G, Aktaş A, Yildirimcan S, Ocakoglu K, Çömelekoğlu Ü. Drug Chem Toxicol. SiO2 Nanoparticule-induced size-dependent genotoxicity - an in vitro study using sister chromatid exchange, micronucleus and comet assay. Drug Chem Toxicol. 2015;38(2):196-204. [CrossRef]

[30] Parveen A, Rizvi SH, Sushma, Mahdi F, Ahmad I, Singh PP, Mahdi AA. Intranasal exposure to silica nanoparticles induce alterations in pro-infammatory environment of rat brain: involvement of oxidative stress. Toxicol Ind Health. 2017;33(2):119-132. [CrossRef]

[31] Mendoza A, Torres-Hernandez JA, Ault JG, Pedersen-Lane JH, Gao D, Lawrence DA. Silica nanoparticles induce oxidative stress and infammation of human peripheral blood mononuclear cells. Cell Stress Chaperones. 2014;19:777790. [CrossRef]

[32] Kim JH, Kim CS, Ignacio RM, Kim DH, Sajo ME, Maeng EH, Qi XF, Park SE, Kim YR, Kim MK, Lee KJ, Kim SK. Immunotoxicity of silicon dioxide nanoparticles with different sizes and electrostatic charge. Int J Nanomed. 2014; 9(Suppl 2):183-193. [CrossRef]

[33] Almansour M, Alarifi S, Jarrar B. In vivo investigation on the chronic hepatotoxicity induced by intraperitoneal administration of 10-nm silicon dioxide nanoparticles. Int J Nanomedicine. 2018; 13:2685-2696. [CrossRef]

[34] Chan WT, Liu CC, Chiang Chiau JS, Tsai ST, Liang CK, Cheng ML, Lee HC, Yeung CY, Hou SY. In vivo toxicologic study of larger silica nanoparticles in mice. Int J Nanomed 2017;12:3421-3432. [CrossRef]

[35] Sies H. Oxidative stress: a concept in redox biology and medicine. Redox Biol. 2015;4:180-183. [CrossRef]

[36] Manke A, Wang L, Rojanasakul Y. Mechanisms of nanoparticle-induced oxidative stress and toxicity. BioMed Res Int. 2013; 2013:1-15. [CrossRef]

[37] Çekiç FÖ, Ekinci S, İnal M S, Özakça D. Silver nanoparticles induced genotoxicity and oxidative stress in tomato plants. Turk J Biol. 2017; 41(5): 700-707. [CrossRef]

[38] Chatterjee N, Jeong J, Yoon D, Kim S, Choi J. Global metabolomics approach in in vitro and in vivo models reveals hepatic glutathione depletion induced by amorphous silica nanoparticles. Chem Biol Interact. 2018;293:100-106. [CrossRef]

[39] Yu Y, Duan J, Li Y, Li Y, Jing L, Yang M, Wang J, Sun Z. Silica nanoparticles induce liver fibrosis via TGF- $\beta_{1} /$ Smad3 pathway in ICR mice. Int J Nanomedicine. 2017; 12:6045-6057. [CrossRef]

[40] Sadek SA, Soliman AM, Marzouk M. Ameliorative effect of Allolobophora caliginosa extract on hepatotoxicity induced by silicon dioxide nanoparticles. Toxicol Ind Health. 2016;32(8):1358-1372. [CrossRef]

[41] Passagne I, Morille M, Rousset M, Pujalté I, L'azou B. Implication of oxidative stress in size-dependent toxicity of silica nanoparticles in kidney cells. Toxicology. 2012;299(2-3):112-124. [CrossRef]

[42] Li J, Li W, Jiang ZG, Ghanbari HA. Oxidative stress and neurodegenerative disorders. Int J Mol Sci 2013; 14(12): 24438-24475. [CrossRef]

[43] Fattin SM, ElSalam NFA, Bahaa N, Baher W. Effect of silica oxide nanoparticles on liver of adult male albino rat. Light and electron microscopic study. EJH 2017;40(3): 345-361. [CrossRef]

[44] Vidya PV, Chitra KC. Sublethal effects of silicon dioxide nanoparticles on the structure of gill, liver and brain tissues in the fish, Oreochromis mossambicus (Peters, 1852). Int J Appl Res. 2018; 4(4): 228-232 
[45] Yu, Y, Li, Y, Wang W, Jin M, Du Z, Li Y, Duan j, Yu Y, Sun, Z. Acute toxicity of amorphous silica nanoparticles in intravenously exposed ICR mice. PloS one. 2013; 8(4): e61346. [CrossRef]

[46] Lai LC, Qian X, Ming CW, Jin F, Na SN, Peng ZX, Ning LY, Hui Y, Zhou Y, Dong JX. Subchronic oral toxicity of silica nanoparticles and silica microparticles in rats. Biomed Environ Sci. 2018; 31(3):197-207. [CrossRef]

[47] Yagi K. Simple procedure for specific enzyme of lipid hydroperoxides in serum or plasma. Methods Mol Biol. 1998; 108:107-110.

[48] Sun Y, Oberley LW, Ying L. A simple method for clinical assay of superoxide dismutase. Clin Chem. 1988; 34: 497500.

[49] Aebi H. Catalase in vitro methods. Enzymol. 1984; 105:121-126.

[50] Lowry OH, Rosenbrough NJ, Farr AL. Protein measurement with the folin phenol reagent. J Biol Chem. 1951;193:265275.

This is an open access article which is publicly available on our journal's website under Institutional Repository at http://dspace.marmara.edu.tr. 